\title{
First Screening of Entomopathogenic Nematodes and Fungus as Biocontrol Agents against an Emerging Pest of Sugarcane, Cacosceles newmannii (Coleoptera: Cerambycidae)
}

\author{
Marion Javal ${ }^{1, *(\mathbb{C}}$, John S. Terblanche ${ }^{1}\left(\mathbb{D}\right.$, Desmond E. Conlong ${ }^{1,2} \mathbb{C}$ and Antoinette P. Malan ${ }^{1}(\mathbb{D}$ \\ 1 Department of Conservation Ecology and Entomology, Faculty of AgriSciences, Stellenbosch University, \\ Private Bag X1, Matieland 7602, South Africa; jst@sun.ac.za (J.S.T.); des.conlong@sugar.org.za (D.E.C.); \\ apm@sun.ac.za (A.P.M.) \\ 2 South African Sugarcane Research Institute, 170 Flanders Drive, Mount Edgecombe, KwaZulu-Natal 4300, \\ South Africa \\ * Correspondence: marion.javal@gmail.com
}

Received: 14 March 2019; Accepted: 16 April 2019; Published: 25 April 2019

\begin{abstract}
Cacosceles newmannii (Coleoptera: Cerambycidae) is an emerging pest of sugarcane in South Africa. The larvae of this cerambycid beetle live within the sugarcane stalk and drill galleries that considerably reduce sugar production. To provide an alternative to chemical control, entomopathogenic nematodes and fungus were investigated as potential biological control agents to be used in an integrated pest management system. The nematodes Steinernema yirgalemense, S. jeffreyense, Heterorhabditis indica, and different concentrations of the fungus Metarhizium pinghaense were screened for efficacy (i.e., mortality rate) against larvae of $C$. newmannii. The different biocontrol agents used, revealed a low level of pathogenicity to $C$. newmannii larvae, when compared to control treatments.
\end{abstract}

Keywords: Cacosceles newmannii; Metarhizium pinghaense; sugarcane; entomopathogens; EPN; EPF; Xenorhabdus khoisanae

\section{Introduction}

The longhorned beetle Cacosceles newmannii Thompson 1877 is a cerambycid native to Mozambique, eSwatini and South Africa. The biology of this beetle is poorly known, and its host plants have not yet been fully determined, but might include species from the Myrtaceae family [1].

Cacosceles newmannii larvae were found in 2015 feeding on commercially grown sugarcane in the KwaZulu-Natal province of South Africa. Larvae dig galleries into the sugarcane stool and upwards from 8 to $20 \mathrm{~cm}$ into the bottom section of the stalk, but are most of the time found in the below-ground section of the sugarcane stalks, in the stool [2]. The reasons underlying the host shift of $C$. newmannii onto sugarcane remain unclear [3]. Regardless of the factor(s) determining the switch to sugarcane, this species has the potential to spread and cause considerable losses.

Cerambycids attacking sugarcane can become serious pests and have severe economic impact worldwide [4-6]. In Thailand, for instance, Dorysthenes buqueti (Guérin-Méneville 1844) (Coleoptera: Cerambycidae) populations increased 10-fold within a year, along with resultant damage observed in the affected sugarcane [7].

Biocontrol includes all plant protection methods that use natural mechanisms, such as parasitism, pathogenicity or predation, and help to complement or reduce the use of chemical insecticide applications in the crop [8]. Biocontrol strategies in integrated pest management are of growing interest in the context of recognized detrimental effects of chemical compounds on ecosystems and human 
health $[9,10]$. Among the various biocontrol agents commonly used, entomopathogenic nematodes (EPNs) have a relatively broad natural host range [11], and have shown their efficiency against many insect species [12] including soil-associated insects [13]. EPNs of the families Steinernematidae and Heterorhabditidae more specifically, occur naturally in soils throughout the world [14,15]. The free-living infective juveniles (IJs) actively move in the soil to find their hosts [16], making them a promising biocontrol agent for soil-associated insects [13] such as C. newmannii. The IJs enter their host through natural openings and in some cases through the cuticle [17]. They then release the symbiotic bacteria they carry in their gut, which rapidly cause the death of the insect [18]. The IJs develop into adults in the haemocoel of the infected insect, feeding on the bacteria. They develop and reproduce within the dead host until all the nutrients have been consumed, and a new cohort of IJs exits the dead insect in search of new hosts [19].

Fungi have also proven their efficacy in controlling sugarcane stem borers [20,21] as well as soil-inhabiting insects [22] including Coleoptera [23,24]. Infection by entomopathogenic fungi (EPF) requires the penetration of conidia into the insect's body and their germination on the insect's cuticle. They are then able to produce lethal toxins that ultimately kill the insects. Unlike nematodes, that are able to seek out their hosts, the conidia are motionless and are spread from the dead insect through air or water [25].

Given the potential for EPNs as biocontrol agents of insects, their effect against insect pests have been widely investigated [12,26], and multiple species have been commercialised worldwide [27]. However, they are globally rather infrequently used, especially in Africa [15], despite the large number of programs dealing with Coleoptera species [23]. Similarly, the increase in understanding of the fungal taxonomy helped develop the use of EPF. In South Africa specifically, the development of entomopathogenic fungi as biocontrol agents has shown an important growth over recent years [28]. However, EPF's success as biocontrol agents is based on a strong investment in research and development, which limits their generalization [25]. Both EPN and EFP can be used as part of integrated pest management programs (IPM), together with other pest control tactics [29].

In this study, we tested the virulence of different locally isolated EPN species and an EPF on C. newmannii larvae.

\section{Materials and Methods}

\subsection{Source of Insects}

Cacosceles newmannii larvae were collected by hand on sugarcane farms in the Entumeni District $\left(28^{\circ} 55^{\prime} S ; 31^{\circ} 19^{\prime} \mathrm{E}\right)$ close to Eshowe, Kwazulu-Natal, South Africa [2]. They were kept in trays with peat and pieces of sugarcane provided as food before the experiments started. Larvae were weighed (Table 1) and cleaned with tap water and blotted dry before each experiment. Specimens are relatively difficult to find en masse in the field; therefore, most experiments could not be replicated.

Table 1. Weight (g) of the Cacosceles newmannii larvae used for experiments 1, 2, 4, 5 and as control, as an indication of the size range of the larvae used.

\begin{tabular}{|c|c|c|c|c|c|c|c|c|c|c|c|}
\hline Experiment/Trial & Treatment & \multicolumn{10}{|c|}{ Specimen Number/Weight (g) } \\
\hline \multirow{3}{*}{$\begin{array}{l}\text { Experiment } 1 \\
\text { trial } 1\end{array}$} & S. yirgalemense & 0.5092 & 0.6696 & 1.1424 & 0.5743 & 1.0989 & 0.133 & 1.9325 & 0.9046 & 1.1363 & 0.1565 \\
\hline & H. indica & 1.1406 & 1.2646 & 0.4083 & 0.2439 & 0.8227 & 0.3296 & 1.8647 & 1.0868 & 0.9111 & 2.0262 \\
\hline & Control & 0.6808 & 1.5231 & 1.1688 & 0.2032 & 0.7458 & 0.2797 & 0.2515 & 0.516 & 1.401 & 0.8454 \\
\hline \multirow{2}{*}{$\begin{array}{l}\text { Experiment } 1 \\
\text { trial } 2\end{array}$} & H. indica & 0.9668 & 0.5257 & 1.1613 & 1.0642 & 0.4061 & 1.1529 & 1.1435 & 0.2527 & 0.6853 & 0.4843 \\
\hline & Control & 0.9822 & 0.8035 & 1.0267 & 1.7146 & 0.6135 & 0.5404 & 0.6147 & 0.5446 & 3.4241 & 1.7076 \\
\hline
\end{tabular}


Table 1. Cont

\begin{tabular}{|c|c|c|c|c|c|c|c|c|c|c|c|}
\hline \multirow{2}{*}{ Experiment/Trial } & \multirow{2}{*}{ Treatment } & \multicolumn{10}{|c|}{ Specimen Number/Weight (g) } \\
\hline & & 1 & 2 & 3 & 4 & 5 & 6 & 7 & 8 & 9 & 10 \\
\hline \multirow{3}{*}{ Experiment 2} & S. yirgalemense & 0.9743 & 1.5439 & 1.5915 & 1.3206 & 1.6647 & & & & & \\
\hline & H. indica & 1.4426 & 0.9689 & 1.6716 & 0.8531 & 1.6249 & & & & & \\
\hline & Control & 1.5206 & 1.3141 & 1.6471 & 0.8701 & 1.3683 & & & & & \\
\hline \multirow{3}{*}{ Experiment 5} & $1 \times 10^{7}$ & 1.4064 & 1.4323 & 0.3762 & 1.9986 & 0.568 & 0.8674 & 0.6631 & 1.0008 & 0.5686 & 1.8468 \\
\hline & $2 \times 10^{7}$ & 1.9988 & 1.4221 & 1.4567 & 2.4397 & 1.0324 & 0.9704 & 0.3289 & 0.8421 & 1.3158 & 0.8968 \\
\hline & Control & 1.778 & 2.2929 & 1.1989 & 1.1747 & 5.8577 & & & & & \\
\hline
\end{tabular}

For the experiments 1, 3, and 4 (see below), Galleria mellonella Linnaeus 1758 (greater wax moth, Lepidoptera: Pyralidae) larvae were used as a positive control, since they are known to be highly susceptible to the EPN used in this study [30]. For the experiment 5, Cydia pomonella Linnaeus 1758 (codling moth, Lepidoptera: Tortricidae) larvae were used as control. Cydia pomonella has been shown to be highly susceptible to several Metarhizium species [31].

\subsection{Entomopathogenic Nematode}

We assessed the virulence of three difference laboratory reared nematode species, Steinernema yirgalemense Nguyen, Tesfamariam, Gozel, Gaugler \& Adams 2004, Steinernema jeffreyense Malan, Knoetze \& Tiedt 2015, and Heterorhabditis indica Poinar, Karunakar \& David 1992, obtained from the EPN collection of the nematology laboratory at the Department of Conservation Ecology and Entomology, Stellenbosch University, South Africa. The three nematode species used naturally occur in South Africa [32], and are listed in Table 2.

Table 2. List and characteristics of the Steinernema and Heterorhabditis species used.

\begin{tabular}{|c|c|c|c|c|c|c|c|}
\hline Species Name & Strain & Habitat & Locality & $\begin{array}{c}\text { GenBank } \\
\text { Accession } \\
\text { Number }\end{array}$ & $\begin{array}{l}\text { Length of } \\
\mathrm{IJ}(\mu \mathrm{m})\end{array}$ & $\begin{array}{l}\text { Body Width } \\
\text { of IJ }(\mu \mathrm{m})\end{array}$ & Reference \\
\hline S. yirgalemense & $157-C$ & $\begin{array}{l}\text { Citrus } \\
\text { orchard }\end{array}$ & $\begin{array}{l}\text { Friedenheim, } \\
\text { Mpumalanga }\end{array}$ & EU625295 & $\begin{array}{c}685 \\
(570-740)\end{array}$ & $\begin{array}{c}29 \\
(24-33)\end{array}$ & [33] \\
\hline S. jeffreyense & J194 & Guava tree & $\begin{array}{l}\text { Jeffrey's Bay, } \\
\text { Eastern } \\
\text { Cape }\end{array}$ & КС897093 & $\begin{array}{c}924 \\
(784-1043)\end{array}$ & $\begin{array}{c}35 \\
(23-43)\end{array}$ & [34] \\
\hline H. indica & SGS & Grapevine & $\begin{array}{c}\text { Bonnievale, } \\
\text { Western } \\
\text { Cape }\end{array}$ & GQ377411 & $\begin{array}{c}528 \\
(479-573)\end{array}$ & $\begin{array}{c}20 \\
(19-22)\end{array}$ & [35] \\
\hline
\end{tabular}

\subsubsection{Experiment 1: EPN Virulence}

Each of the three nematode species was inoculated to 10 C. newmannii larvae per treatment, along with $10 \mathrm{G}$. mellonella larvae used as a positive control. After weighing, each larva was placed individually in a $9 \mathrm{~cm}$ diam. Petri dish, to which a filter paper disk, moistened by adding $350 \mu \mathrm{L}$ of distilled water, was added. Fifty $\mu \mathrm{L}$ containing 400 infective juveniles (IJ) were then pipetted on the filter paper of each of the 10 Petri dishes, for each nematode treatment $(n=30)$ [36]. Ten additional C. newmannii larvae were used as a negative control and received only $400 \mu \mathrm{L}$ of water. The lid of each Petri dish was sealed with Parafilm (Pechiney Plastic Packaging, Neenah, WI, USA) to prevent the escape of insects. Petri dishes were then placed in a plastic container (one container per treatment), lined with wet paper towels to ensure air high humidity, and kept in an incubator at $25^{\circ} \mathrm{C}$. Generally, entomopathogenic nematodes are able to penetrate their host within 12 to $24 \mathrm{~h}$ [36]. However, larval mortality was checked every day for 3 days. Cause of mortality was confirmed by dissecting the dead 
larvae, with the aid of a light microscope, and visually determining the presence of nematodes inside the larvae. The experiment was conducted twice (trials 1 and 2) in order to confirm results. The total numbers of dead larvae per nematode species were then compared using a Pearson's Chi-squared test in $\mathrm{R}$ (version 3.3.0 [37]). In all cases, we used a significance level of $5 \%$.

\subsubsection{Experiment 2: Nematode Penetration}

In order to confirm that nematodes were capable of effectively penetrating and entering the body of the insect, five C. newmannii larvae were inoculated again with a high number of nematodes (1000 IJs per larva), following the same protocol as described above, and kept at $25^{\circ} \mathrm{C}$ for 2 days before being killed and dissected. Before dissection the larvae were washed with water to remove nematodes from the surface of the insects. The number of nematodes per insect was then scored with the aid of a light microscope, and the penetration value was computed according to the following formula [36]:

$$
P=\frac{N \times 100}{T}
$$

$P$ being the penetration value, $N$, the average number of nematodes found in each larva and $T$ the initial number of nematodes inoculated per larva. The three values of $P$ were then statistically compared using a one sample t-test in R.

\subsubsection{Experiment 3: Nematode Development in Haemolymph}

Steinernema jeffreyense was the only nematode species causing mortality of a C. newmannii larva (see Results). However, given the low pathogenicity level observed, additional experiments were performed to aid the understanding of the potential mechanisms involved in insect resistance. Ten C. newmannii were washed with distilled water, dried and perforated with a sterile insulin needle. A droplet of haemolymph was collected in a Petri dish, and immediately inoculated with $S$. jeffreyense IJs. The same protocol was repeated using $10 \mathrm{G}$. mellonella larvae as a control. Between 7 and 14 IJs were inoculated per droplet of haemolymph. The Petri dishes were then sealed with Parafilm, placed in a plastic container with wet paper towels and kept in an incubator at $25^{\circ} \mathrm{C}$. The numbers of males, females with and without eggs, IJs, and dead nematodes were checked after $48 \mathrm{~h}$. Then, only the presence of progeny, and of fertilized females was recorded 72, 96 and $120 \mathrm{~h}$ after inoculation.

\subsubsection{Experiment 4: Virulence of Mutualistic Bacteria}

Last, we tested whether the low level of pathogenicity of $S$. jeffreyense could be due to the inability of the nematode's symbiotic bacteria, Xenorhabdus khoisanae Ferreira, Van Reenen, Endo, Sproër, Malan \& Dicks 2013 [38], to grow in the insect's haemolymph. The bacteria cell concentration of $1 \times 10^{7} \mathrm{cells} / \mathrm{ml}$ was determined by counting the cells using a haemocytometer [39]. Larvae were first washed with pure ethanol. We then injected $2 \mu \mathrm{L}$ of a suspension of bacteria in tryptic soy broth into C. newmannii larvae using sterile insulin needles, and volumes between 1 and $10 \mu \mathrm{L}$ were injected in G. mellonella larvae as a positive control. In addition, $2 \mu \mathrm{L}$ of distilled water was injected in five $C$. newmannii larvae as a negative control. Mortality was checked every day for 5 days. All insects injected with bacteria were dissected after death.

\subsection{Experiment 5: Virulence of EPF}

We assessed the virulence of Metarhizium pinghaense Chen \& Guo 1986 (Ascomycota: Hypocreales: Clavicipitaceae) at two different concentrations $\left(1 \times 10^{7}\right.$ and $2 \times 10^{7}$ spores per $\left.\mathrm{mL}\right)$. Metarhizium pinghaense (previously identified as M. anisopliae) has been successfully commercialised in other countries $[40,41]$. The South African strain of $M$. pinghaense used in this study was isolated from an apple orchard and showed to be effective against codling moth and woolly apple aphid [42]. 
The conidia were freshly produced on Sabouraud dextrose agar (SDA) plates. Preliminary germination tests of freshly cultured conidia of $M$. pinghaense showed $>90 \%$ germination of conidia in all cases. In order to determine the conidial concentration, $0.05 \%$ Tween 20 was added as a standard, to be able to get the conidia into suspension.

After weighing, C. newmannii larvae were dipped in a suspension of the fungal isolates $(n=10$ larvae per concentration) for $15 \mathrm{sec}$, and placed in an empty petri dish for about $5 \mathrm{~min}$ in order to dry. Larvae were then covered by autoclaved peat, and distilled water was added to provide enough moisture for the larvae and the fungus to survive. Five $C$. newmannii larvae were used as a negative control and were dipped in water for 15 seconds, before being covered with wet peat. Ten C. pomonella larvae were used as a positive control for each concentration.

Petri dishes were placed in an incubator at $25^{\circ} \mathrm{C}$, and larval mortality was then checked every week for three weeks. Cause of mortality was confirmed visually by the presence mycosis on the dead larvae, and the mortality levels observed after 21 days were statistically compared using a chi-squared test, followed by multiple comparisons using $\mathrm{R}$ version 3.3.0 [37].

\section{Results}

\subsection{Nematodes}

\subsubsection{Experiment 1: EPN Virulence}

In the first trial, none of the negative control C. newmannii larvae died, and three out of 10 were dead at the end of the second trial (Figure 1). All positive control (G. mellonella larvae) were infected and dead by the end of the trials. After 72 hours, the number of dead C. newmannii larvae per nematode species ranged between 2 and 4 out of 20 specimens, with $80 \%$ to $90 \%$ being alive, for both trials combined. The number of dead specimens for each nematode species did not differ from each other $\left(X^{2}=0.7843, p\right.$-value $\left.=0.8532\right)$.

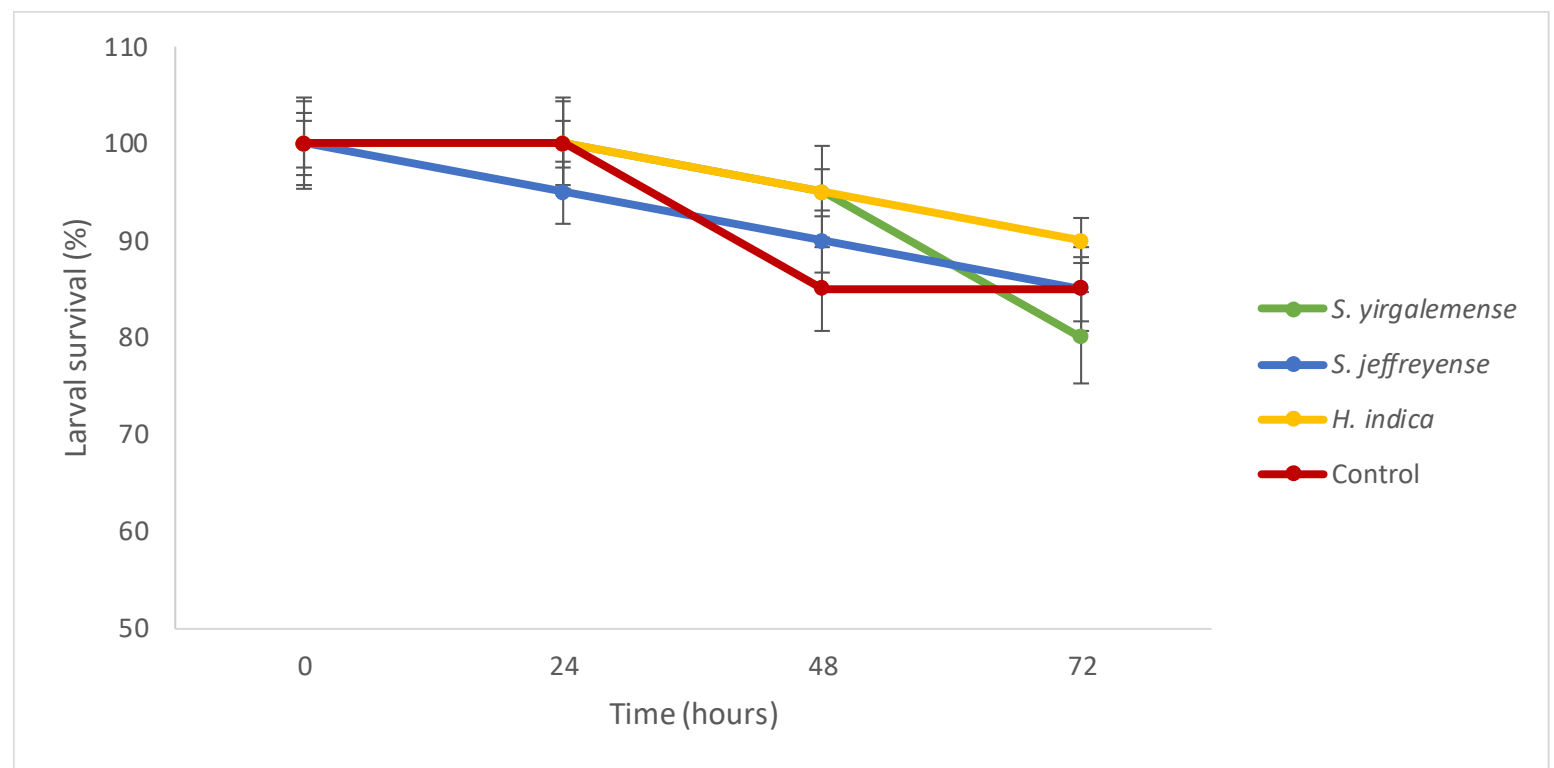

Figure 1. Percentage of Cacosceles newmannii larvae surviving infection by the three nematodes species, for both trials combined. Data is shown with standard errors of the mean (SEM).

Dissection of the dead C. newmannii larvae revealed that only one larva of the first trial was infected by S. jeffreyense (Video S1). 


\subsubsection{Experiment 2: Nematode Penetration}

The number of nematodes found in the C. newmannii larvae inoculated with a high number of IJs are reported in Table 3, which ranged from 4 to 28 nematodes per insect. All larvae were still alive after the 48 hours of incubation. The penetration values associated with each nematode species were not significantly different $(t=0.0271, p$-value $=0.9809)$.

Table 3. Number of nematodes found per Cacosceles newmannii larva inoculated with a high concentration of IJs, for the three nematodes species used.

\begin{tabular}{ccccccc}
\hline Specimen Number & $\mathbf{1}$ & $\mathbf{2}$ & $\mathbf{3}$ & $\mathbf{4}$ & $\mathbf{5}$ & $\begin{array}{c}\text { Penetration } \\
\text { Value }\end{array}$ \\
\hline Steinernema yirgalemense & 8 & 17 & 25 & 4 & 11 & 1.3 \\
\hline Steinernema jeffreyense & 10 & 5 & 13 & 10 & 4 & 4.2 \\
\hline Heterorhabditis indica & 14 & 25 & 28 & 21 & 9 & 9.7 \\
\hline
\end{tabular}

\subsubsection{Experiment 3: Nematode Development in Haemolymph}

When a drop of haemolymph was inoculated with $S$. jeffreyense nematodes, a marked difference was observed between the control (G. mellonella haemolymph) and the tested C. newmannii haemolymph. In the control haemolymph, most inoculated IJs developed into adults, most females had been fertilized after only $48 \mathrm{~h}$, and progeny was visible and abundant between $72 \mathrm{~h}$ and $96 \mathrm{~h}$ after inoculation (Table 4 , Figure 2). When C. newmannii haemolymph was inoculated, on the other hand, most nematodes were still unrecovered (non-feeding) IJs after $48 \mathrm{~h}$ (Figure 2). Progeny was visible in two replicates after $96 \mathrm{~h}$, and in 3 replicates after $120 \mathrm{~h}$ (Table 4 ) but were scarce and lethargic. Visual observation showed that nematodes were much more active in G. mellonella haemolymph than in C. newmannii haemolymph, and tended to be bigger. However, these observations were not formally quantified.

Table 4. Number of females, males, IJs, and dead Steinernema jeffreyense $48 \mathrm{~h}$ after inoculation in the haemolymph, and status of the nematodes ( $\mathrm{P}=$ progeny, $\mathrm{E}=$ females with eggs) 72,96 and $120 \mathrm{~h}$ after inoculation. * indicate a peculiarly low level of progeny.

\begin{tabular}{|c|c|c|c|c|c|c|c|c|c|}
\hline & \multicolumn{6}{|c|}{$48 \mathrm{~h}$} & \multirow{2}{*}{$\begin{array}{c}72 \mathrm{~h} \\
\text { Status }\end{array}$} & \multirow{2}{*}{$\begin{array}{c}96 \mathrm{~h} \\
\text { Status }\end{array}$} & \multirow{2}{*}{$\begin{array}{l}120 \mathrm{~h} \\
\text { Status }\end{array}$} \\
\hline Galleria mellonella & Females & $\begin{array}{c}\text { Females } \\
\text { with Eggs }\end{array}$ & Males & $\begin{array}{l}\text { Infective } \\
\text { Juveniles }\end{array}$ & Dead & $\begin{array}{c}\text { Total } \\
\text { Inoculated }\end{array}$ & & & \\
\hline 2 & 2 & 1 & 6 & 2 & 0 & 10 & $\mathrm{E}$ & $\mathrm{P}$ & $\mathrm{P}$ \\
\hline 3 & 3 & 2 & 1 & 2 & 1 & 7 & $\mathrm{E}$ & $\mathrm{P}$ & $\mathrm{P}$ \\
\hline 4 & 10 & 10 & 3 & 1 & 0 & 14 & $\mathrm{P}$ & $\mathrm{P}$ & $\mathrm{P}$ \\
\hline 6 & 1 & 0 & 4 & 0 & 3 & 8 & - & $\mathrm{E}$ & $\mathrm{P}$ \\
\hline 7 & 2 & 2 & 5 & 1 & 0 & 8 & $\mathrm{E}$ & $\mathrm{P}$ & $\mathrm{P}$ \\
\hline 8 & 7 & 7 & 4 & 0 & 0 & 11 & $\mathrm{P}$ & $\mathrm{P}$ & $\mathrm{P}$ \\
\hline 9 & 6 & 1 & 2 & 0 & 0 & 8 & $\mathrm{E}$ & $\mathrm{P}$ & $\mathrm{P}$ \\
\hline 10 & 1 & 0 & 5 & 4 & 0 & 10 & $\mathrm{E}$ & $\mathrm{P}$ & $\mathrm{P}$ \\
\hline 1 & 0 & 0 & 1 & 9 & 0 & 10 & - & - & - \\
\hline 2 & 0 & 0 & 6 & 3 & 0 & 9 & - & - & - \\
\hline 3 & 4 & 0 & 5 & 4 & 0 & 13 & - & - & - \\
\hline 4 & 0 & 0 & 2 & 5 & 0 & 7 & - & - & - \\
\hline 5 & 4 & 0 & 2 & 2 & 0 & 8 & $\mathrm{E}$ & $\mathrm{E}$ & $\mathrm{P}^{*}$ \\
\hline 6 & 1 & 0 & 3 & 5 & 0 & 9 & - & - & - \\
\hline 7 & 1 & 0 & 6 & 1 & 0 & 8 & $\mathrm{E}$ & $\mathrm{E}$ & $\mathrm{E}$ \\
\hline 8 & 2 & 0 & 2 & 0 & 3 & 7 & - & $\mathrm{P}^{*}$ & $\mathrm{P}^{*}$ \\
\hline 9 & 1 & 0 & 2 & 7 & 0 & 10 & $\mathrm{E}$ & $\mathrm{P}^{*}$ & $\mathrm{P}^{*}$ \\
\hline 10 & 2 & 0 & 5 & 1 & 0 & 8 & - & - & - \\
\hline
\end{tabular}




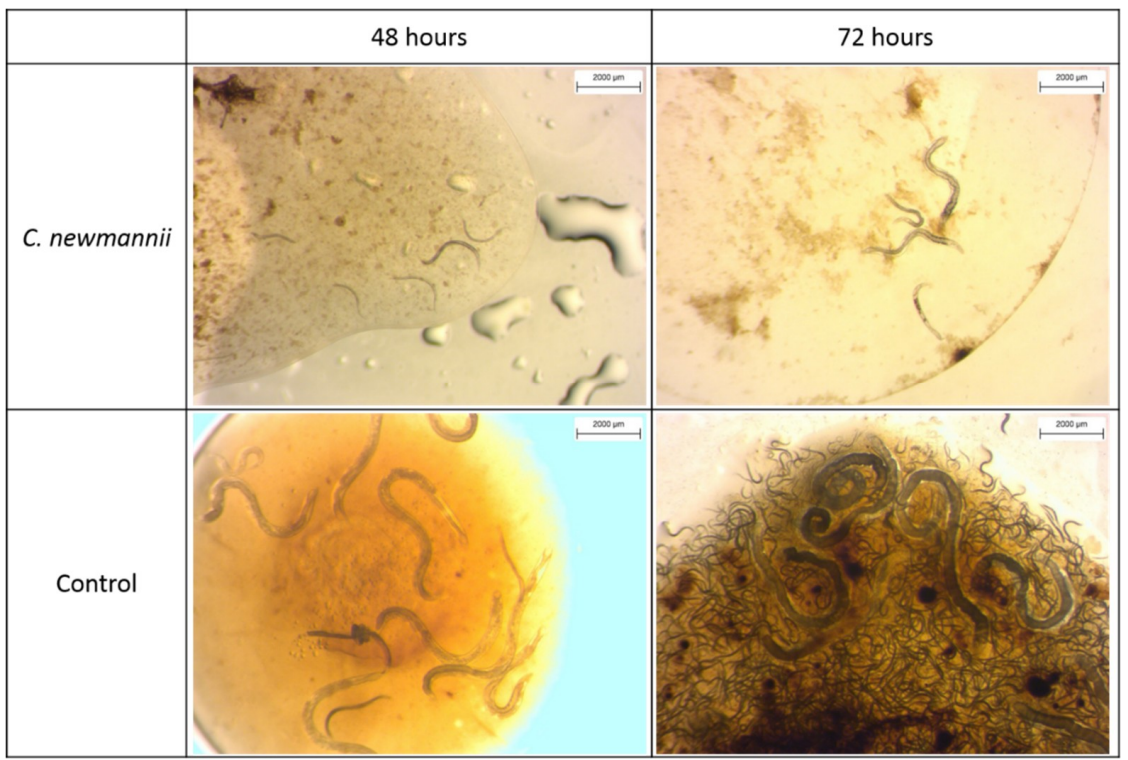

Figure 2. Steinernema jeffreyense inoculated in Cacosceles newmannii haemolymph (top) and Galleria mellonella haemolymph (control, bottom), $48 \mathrm{~h}$ and $72 \mathrm{~h}$ after inoculation.

\subsubsection{Experiment 4: Virulence of Mutualistic Bacteria}

Finally, when bacteria were injected into C. newmannii larvae, five dead specimens were reported after $48 \mathrm{~h}$, the five remaining ones being relatively inactive. After 5 days, all 10 replicates were dead. Control replicates ( $G$. mellonella larvae) that had been injected with bacteria all died after less than $24 \mathrm{~h}$, regardless of the volume of bacterial suspension injected. Dissections showed that all internal organs were dissolved for G. mellonella larvae, whereas organs were still intact in C. newmannii larvae, indicating that the bacteria did develop in G. mellonella larvae, but not in C. newmannii larvae. The $C$. newmannii larvae injected with $2 \mu \mathrm{L}$ of distilled water survived the treatment and were still alive after 5 days, indicating that the liquid injection itself did not alter the larval survival.

\subsection{Experiment 5: Virulence of EPF}

All positive controls were dead and showed clear sign of infection by M. pinghaense at the end of the first week. No death was observed among the negative $C$. newmannii control before the 3rd week of the experiment, whereas $C$. newmannii larvae in contact with the fungus started to die from the first week (Figure 3).

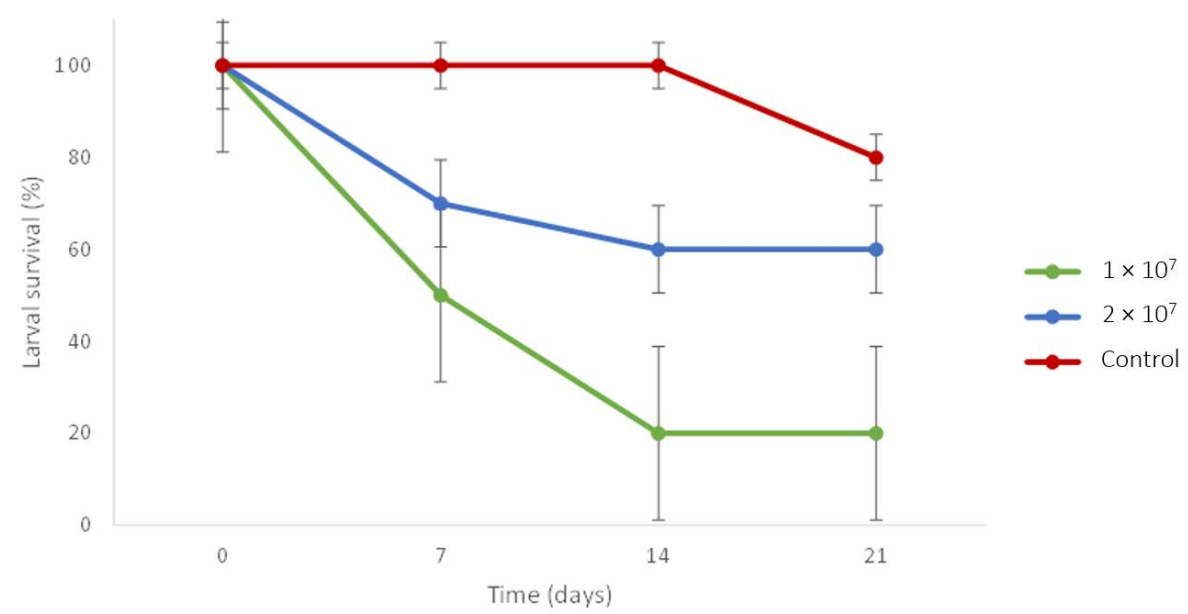

Figure 3. Percentage of larvae surviving infection by $M$. pinghaense at two different concentrations. Data is shown with SEM. 
Overall, the mortality rates observed at each of the two concentrations and for the control treatment differed significantly $\left(X^{2}=7.5, p\right.$-value $\left.=0.0235\right)$. Multiple comparisons however showed that only the lowest concentration $\left(1 \times 10^{7}\right.$ spores per $\mathrm{mL}$ of water $)$ and the control treatment significantly differed in terms of mortality of 21 days $\left(X^{2}=7.2, p\right.$-value $\left.=0.0073\right)$. Even though the comparison was non-significant $\left(X^{2}=3.3, p\right.$-value $\left.=0.0679\right)$, the mortality rate was always higher for the lower concentration of spores (Figure 3), and only $20 \%$ of the larvae exposed to the lowest concentration of spores $\left(1 \times 10^{7}\right.$ spores per $\mathrm{mL}$ of water) were still alive by the end of the experiment, whereas $60 \%$ of the larvae exposed at the higher concentration $\left(2 \times 10^{7}\right.$ spores per $\mathrm{mL}$ of water) survived. However, none of the C. newmannii specimens died because of the fungus itself, since none of the dead insects showed characteristic signs of mycosis.

\section{Discussion}

This study is the first to assess the virulence of EPNs and an entomopathogenic fungus in the context of biocontrol of larvae of the cerambycid C. newmannii. Overall, larvae of this emerging crop pest appear to be resistant to the different EPN and EPF species used in this study.

Despite the promising results that nematodes gave on other diverse insect pest species [13,43], S. yirgalemense, S. jeffreyense, and $H$. indica did not cause an increase in larval mortality compared to the negative control. Several insect species have already shown strong resistance to EPNs, and this resistance can be due to a large variety of factors, including immune defense against nematodes, or interaction with the biotic and abiotic environments [12,44]. Many of these species spend their entire larval stage in the soil, and therefore are in permanent contact with the soil environment. One hypothesis could be that these species have developed mechanisms of resistance against nematode infections that are not present in species whose larval development largely happens in a nematode-free environment, such as above ground insects. Moreover, a strong and rapid encapsulation response has been observed in C. newmannii larvae suggestive of a pronounced immune response.

In the case of $C$. newmannii, only $S$. jeffreyense caused larval mortality. However, only a very small number of larvae were killed ( 1 in 20). Given this very low pathogenicity, and despite the fact that the larvae that died did not show any abnormal signs of stress, it is questionable whether the physiological state of that single individual (stress, insect approaching moulting) might have played a role in its weak resistance to $S$. jeffreyense.

Additional experiments have been conducted to understand how the development of EPNs is limited. Even when inoculated at very high concentrations, few nematodes successfully penetrated the body of $C$. newmannii larvae, and this was true for all three EPN species studied. A barrier therefore exists at the first step of infection, which can possibly be ascribed to either the IJs were not attracted to the C. newmannii larvae [45], or were not able enter the insect in large numbers, because of physical or behaviour barriers [44].

In addition, once inside the $C$. newmannii larva, in the haemolymph, EPNs have difficulty developing. The time required for their full development was longer than in an insect susceptible to EPNs, and they were not able to produce abundant offspring. This rather long, or even non-existent development, is related to the apparent lack of development of X. khoisanae in the haemolymph of the larvae of $C$. newmannii. This bacterium is normally vectored by the IJs in the host's body, contributes to its death by causing septicaemia, and provides a source of nutrient for the nematodes [46]. In the case of $C$. newmannii, the bacteria do not develop. This explains why IJs could survive but not grow, their main nutrient source being absent. The $C$. newmannii larvae in which the bacteria were injected died long after the G. mellonella control larvae, and did not show symptoms of bacterial infection. We hypothesize that even though the bacteria were not able to grow in C. newmannii larvae, they were still able to release toxins into their environment, hence the progressive death of the larvae studied.

EPF have shown promising results with another pest of sugarcane with a similar life cycle, D. buqueti, in Thailand $[20,21]$. The EPF species M. pinghaense used in this study considerably altered larval survival rate, especially for the larvae exposed to the lowest concentration of spores. However, 
visual examination of the dead specimens did not reveal the standard signs of fungal infection, suggesting that their death was due to another factor that we were not able to identify.

\section{Conclusions}

IPM is a holistic approach that aims at reducing pest populations' density, while limiting pesticide use and therefore increasing environment and human health [29]. It implies the use of multiple, complementary methods, that in some cases can work synergistically (i.e., [47] for grasshoppers and locusts; [25]). Indeed, some biological control techniques benefit from being used in conjunction with other strategies.

Even though the EPN and EPF species used in this study showed a rather low pathogenicity level, infection by one EPN species (S. jeffreyense) and one EPF species (M. pinghaense, however the mechanisms involved in the death of larvae still need to be investigated) lead to the death of some larvae. Before discarding them as potential biocontrol agents as part of an IPM program, their pathogenicity needs to be investigated when coupled with other biopesticides or natural enemies.

Supplementary Materials: The following are available online at http://www.mdpi.com/2075-4450/10/4/117/s1, Video S1: Steinernema jeffreyense infection on a Cacosceles newmannii larva.

Author Contributions: Conceptualization, M.J., D.E.C. and A.P.M.; Formal analysis, M.J. and A.P.M.; Funding acquisition, J.S.T. and D.E.C.; Methodology, M.J. and A.P.M.; Project administration, M.J., J.S.T. and D.E.C.; Writing - original draft, M.J.; Writing - review \& editing, M.J., J.S.T., D.E.C. and A.P.M.

Funding: This research was supported by funding from the Centre for Invasion Biology and the South African Sugarcane Research Institute.

Acknowledgments: The authors thank Letodi Luki Mathulwe and Saskia Thomas for laboratory assistance. Denise Gillespie and Nelson Muthusamy are thanked for ensuring the survival of the C. newmannii, larvae once received in the SASRI insect rearing unit, and for shipping the larvae to Stellenbosch University, and the Entumeni Pest and Disease team for collecting the larvae from infested sugarcane fields.

Conflicts of Interest: The authors declare no conflict of interest. The funders had no role in the design of the study; in the collection, analyses, or interpretation of data; in the writing of the manuscript, or in the decision to publish the results.

\section{References}

1. Ferreira, G.W.S. The Parandrinae and the Prioninae of Southern Africa (Cerambycidae, Coleoptera); Memoir nr 13, Memoirs van die Nasionale Museum, Posbus 266; National Museum: Bloemfontein, South Africa, 1980; p. 334.

2. Way, M.J.; Conlong, D.E.; Rutherford, R.S.; Sweby, D.L.; Gillespie, D.Y.; Stranack, R.A.; Lagerwall, G.; Grobbelaar, E.; Perissinotto, R. Cacosceles (Zelogenes) newmannii (Thomson) (Cerambycidae:Prioninae), a new pest in the South African sugarcane industry. In Proceedings of the 90th Annual Congress of the South African Sugar Technologists Association, Durban, South Africa, 15-17 August 2017; Volume 90, pp. 62-65.

3. Javal, M.; Thomas, S.; Barton, M.G.; Gillespie, D.; Conlong, D.E.; Terblanche, J.S. Understanding the recent invasion of Cacosceles newmannii (Coleoptera: Cerambycidae) into sugarcane from a thermal perspective. In Proceedings of the 91st Annual Congress of the South African Sugar Technologists Association, Durban, South Africa, 14-16 August 2018; Volume 91, pp. 66-69.

4. Oyafuso, A.; Arakaki, N.; Sadoyama, Y.; Kishita, M.; Kawamura, F.; Ishimine, M.; Kinjo, M.; Hirai, Y. Life history of the white grub Dasylepida sp. (Coleoptera: Scarabaeidae), a new and severe pest on sugarcane on the Miyako Islands, Okinawa. Appl. Entomol. Zool. 2002, 37, 595-601. [CrossRef]

5. Mukunthen, N.; Nirmala, R. New insect pests of sugarcane in India. SugarTech 2002, 4, 157-159. [CrossRef]

6. Dolinski, C.; Del Valle, E.; Stuart, R.J. Virulence of entomopathogenic nematodes to larvae of the guava weevil, Conotrachelus psidii (Coleoptera: Curculionidae), in laboratory and greenhouse experiments. Biol. Control 2006, 38, 422-427. [CrossRef] 
7. Pliansinchai, U.; Jarnkoon, V.; Siengsri, S.; Kaenkong, C.; Pangma, S.; Weerathaworn, P. Ecology and destructive behaviour of cane boring grub (Dorysthenes buqueti Guerin) in North Eastern Thailand. In Proceedings of the XXVI Congress of the International Society of Sugar Cane Technologists, Durban, South Africa, 29 July-2 August 2007; pp. 863-867.

8. Fravel, D.R. Commercialization and implementation of biocontrol. Annu. Rev. Phytopathol. 2005, 43, 337-359. [CrossRef] [PubMed]

9. Lacey, L.A.; Frutos, R.; Kaya, H.K.; Vail, P. Insect pathogens as biological control agents: Do they have a future? Biol. Control 2001, 21, 230-248. [CrossRef]

10. Bourguet, D.; Guillemaud, T. The hidden and external costs of pesticide use. Sustain. Agric. Rev. 2016, 19, 35-120. [CrossRef]

11. Peters, A. The natural host range of Steinernema and Heterorhabditis spp. and their impact on insect populations. Biocontrol Sci. Technol. 1996, 6, 389-402. [CrossRef]

12. Labaude, S.; Griffin, C.T. Transmission success of entomopathogenic nematodes used in pest control. Insects 2018, 9, 72. [CrossRef]

13. Campos-Herrera, R. Nematode Pathogenesis of Insects and Other Pests: Ecology and Applied Technologies for Sustainable Plant and Crop Protection; Springer International Publishing: Basel, Switzerland, 2015; 531p.

14. Poinar, G. Entomopathogenic nematodes in biological control. In Taxonomy and Biology of Steinernematidae and Heterorhabditidae; Gaugler, R., Kaya, H.K., Eds.; CRC Press: Boca Raton, FL, USA, 1990; pp. 23-74.

15. Kaya, H.K.; Aguillera, M.M.; Alumai, A.; Choo, H.Y.; de la Torre, M.; Fodor, A.; Ganguly, S.; Hazır, S.; Lakatos, T.; Pye, A.; et al. Status of entomopathogenic nematodes and their symbiotic bacteria from selected countries or regions of the world. Biol. Control 2006, 38, 134-155. [CrossRef]

16. Schroeder, W.J.; Beavers, J.B. Movement of the Entomogenous Nematodes of the Families Heterorhabditidae and Steinernematidae in Soil. J. Nematol. 1987, 19, 257-259. [PubMed]

17. Poinar, G.O. Nematodes for Biological Control of Insects; CRC Press, Inc.: Boca Raton, FL, USA, 1979; 277p.

18. Simões, N.; Rosa, J.S. Pathogenicity and host specificity of entomopathogenic nematodes. Biocontrol Sci. Technol. 1996, 6, 403-411. [CrossRef]

19. Ehlers, R.-U. Mass production of entomopathogenic nematodes for plant protection. Appl. Microbiol. Biotechnol. 2001, 56, 623-633. [CrossRef]

20. Suasa-ard, W.; Suksen, K.; Kernasa, O. Utilisation of the green muscardine, Metarhizium anisopliae, to controle the sugarcane longhorne stem borer Dorysthenes buqueti Guerin (Coleoptera: Cerambycidae). Int. Sugar J. 2012, 114, 37-40.

21. Suasa-ard, W.; Sommartya, P.; Buchatian, P.; Puntongcum, A.; Chiangsin, R. Effect of Metarhizium anisopliae on infection of sugarcane stems borer, Dorysthenes buqueti Guerin (Coleoptera: Cerambycidae) in laboratory. In Proceedings of the 46th Kasetsart University Annual Conference, Kasetsart, Thailand, 29 January-1 February 2008; pp. 155-160.

22. Jackson, M.A.; Jaronskib, S.T. Production of microsclerotia of the fungal entomopathogen Metarhizium anisopliae and their potential for use as a biocontrol agent for soil-inhabiting insects. Mycol. Res. 2009, 113, 842-850. [CrossRef]

23. Hajek, A.E.; McManus, M.L.; Delalibera, I. A review of introductions of pathogens and nematodes for classical biological control of insects and mites. Biol. Control 2007, 41, 1-13. [CrossRef]

24. Marannino, P.; Santiago-Álvarez, C.; de Lillo, E.; Quesada-Moraga, E. Evaluation of Metarhizium anisopliae (Metsch) Sorok. to target larvae and adults of Capnodis tenebrionis (L.) (Coleoptera: Buprestidae) in soil and fiber band applications. J. Invertebr. Pathol. 2008, 97, 237-244. [CrossRef]

25. Shah, P.A.; Pell, J.K. Entomopathogenic fungi as biological control agents. Appl. Microbiol. Biotechnol. 2003, 61, 413-423. [CrossRef]

26. Malan, A.P.; Ferreira, T. Entomopathogenic nematodes. In Nematology in South Africa: A View from the 21st Century; Fourie, H., Spaull, V.W., Jones, R.K., Daneel, M.S., De Waele, D., Eds.; Springer International: Cham, Switzerland, 2017; pp. 459-480.

27. Ehlers, R.-U. Current and future use of nematodes in biocontrol: Practice and commercial aspects with regard to regulatory policy issues. Biocontrol Sci. Technol. 1996, 6, 303-316. [CrossRef]

28. Hatting, J.L.; Moore, S.D.; Malan, A.P. Microbial control of phytophagous invertebrate pests in South Africa: Current status and future prospects. J. Invertebr. Pathol. 2018. [CrossRef] 
29. Ehler, L.E. Integrated pest management (IPM): Definition, historical development and implementation, and the other IPM. Pest Manag. Sci. 2006, 62, 787-789. [CrossRef]

30. Van Zyl, C.; Malan, A.P. Cost-effective culturing of Galleria mellonella and Tenebrio molitor and nematode production in various hosts. Afr. Entomol. 2015, 23, 361-375. [CrossRef]

31. Abaajeh, A.R.; Nchu, F. Isolation and pathogenicity of some South African entomopathogenic fungi (Ascomycota) against eggs and larvae of Cydia pomonella (Lepidoptera: Tortricidae). Biocontrol Sci. Technol. 2015, 25, 828-842. [CrossRef]

32. Malan, A.P.; Nguyen, K.B.; Addison, M.F. Entomopathogenic nematodes (Steinernematidae and Heterorhabditidae) from the southwestern parts of South Africa. Afr. Plant Prot. 2006, 12, 65-69.

33. Malan, A.P.; Knoetze, R.; Moore, S.D. Isolation and identification of entomopathogenic nematodes from citrus orchards and their biocontrol potential against false codling moth. J. Invertebr. Patholol. 2011, 108, 115-125. [CrossRef]

34. Malan, A.P.; Knoetze, R.; Tiedt, L.R. Steinernema jeffreyense n. sp. (Rhabditida: Steinernematidae), new entomopathogenic nematode from South Africa. J. Helminthol. 2016, 90, 262-278. [CrossRef]

35. Poinar, G.O., Jr.; Karunakar, G.K.; David, H. Heterorhabditis indicus n. sp. (Rhabditida: Nematoda) fom India: Separation of Heterorhabditis spp. by infective juveniles. Fundam. Appl. Nematol. 1992, 15, 467-472.

36. Glazer, I.; Lewis, E.E. Bioassays for entomopathogenic nematodes. In Bioassays of Entomopathogenic Microbes and Nematodes; Navon, A., Ascher, K.R.S., Eds.; CABI Publishing: Wallingford, UK, 2000; pp. 229-248.

37. R Core Team. R: A Language and Environment for Statistical Computing; R Foundation for Statistical Computing: Vienna, Austria, 2016.

38. Dreyer, J.; Malan, A.P.; Dicks, L.M.T. Three novel Xenorhabdus-Steinernema associations and evidence of strains of X. khoisanae switching between different clades. Curr. Microbiol. 2017, 74, 938-942. [CrossRef]

39. Ferreira, T.; Malan, A.P. In vitro Liquid Culture of a South African Isolate of Heterorhabditis zealandica for the Control of Insect Pests. Afr. Entomol. 2014, 22, 80-92. [CrossRef]

40. Ekesi, S.; Chabi-Olaye, A.; Subramanian, S.; Borgemeister, C. Horticultural pest management and the African economy: Successes, challenges and opportunities in a changing global environment. Acta Hortic. 2011, 911, 165-183. [CrossRef]

41. Brunner-Mendoza, C.; Del Rocío Reyes-Montes, M.; Moonjely, S.; Bidochka, M.J.; Toriello, C. A review on the genus Metarhizium as an entomopathogenic microbial biocontrol agent with emphasis on its use and utility in Mexico. Biocontrol Sci. Technol. 2019, 29, 83-102. [CrossRef]

42. Mathulwe, L.L. Control of the Woolly Apple Aphid, Eriosoma lanigerum (Hausmann) (Hemiptera: Aphididae), Using Entomopathogenic Fungi. Master's Thesis, University of Stellenbosch, Stellenbosch, South Africa, 2019.

43. Malan, A.P.; Hatting, J. Entomopathogenic Nematode Exploitation: Case Studies in Laboratory and Field Applications from South Africa. In Sustainability in Plant and Crop Protection: Ecology and Applied Technologies for Sustainable Plant and Crop Protection; Campos-Herrera, R., Ed.; Springer: Cham, Switzerland, 2015; pp. 475-506.

44. Narayanan, K. Insect defence: Its impact on microbial control of insect pests. Curr. Sci. 2006, 86, 800-814.

45. Baiocchi, T.; Lee, G.; Chloe, D.-H.; Dillman, A.R. Host seeking parasitic nematodes use specific odors to assess host resources. Sci. Rep. 2017, 7, 6270. [CrossRef]

46. Banu, J.G.; Gannayane, I.; Meena, K.S. Entomopathogenic nematodes: General biology and behaviour. In Biocontrol Agents Entomopathogenic and Slug Parasitic Nematodes; Abd-Elgawad, M., Askary, T.H., Coupland, J., Eds.; CABI Publishing: Wallingford, UK, 2017; pp. 63-87.

47. Lomer, C.J.; Bateman, R.P.; Johnson, D.L.; Langewald, J.; Thomas, M. Biological control of locusts and grasshoppers. Annu. Rev. Entomol. 2001, 46, 667-702. [CrossRef]

(C) 2019 by the authors. Licensee MDPI, Basel, Switzerland. This article is an open access article distributed under the terms and conditions of the Creative Commons Attribution (CC BY) license (http://creativecommons.org/licenses/by/4.0/). 